\title{
BLINDNESS, EYE DISEASES AND THEIR CAUSES IN THE LAND OF CANAAN
}

BY

\author{
N. I. Shimkin, M.D., Ph.D. \\ HAIFA, PALESTINE
}

THE object of this paper is to answer the question :-Were blindness and eye diseases resulting in blindness widespread in ancient Palestine in that bygone time when this country was called the land of Canaan, or is this social evil of present-day Palestine a sad acquisition of recent times?

The epoch dealt with begins in 1400 B.c., i.e., when the name of the Khabiru people is mentioned for the first time in the Tel-Amarna tablets. The majority of scientists hold that the "Khabiru" are Hebrews, and identify this time with the coming of Abraham and his tribe into the land of Canaan. The end of the investigated epoch refers to about 1000 B.c., i.e., to the time of the conquest by King David of all Canaan, except the small coastal plain, from the South of Jaffa to Gaza which was inhabited by the Philistines.

The boundaries of the land of Canaan almost coincide with those of the populated part of modern Palestine, which makes up 53 per cent. of all its territory comprising about 10,000 square miles; the remaining 47 per cent. represent as yet an almost uninhabited desert to the south of Beersheba, with a population of 50,000 in all this region. (Census of Palestine.)

The land of Canaan was, as now, bounded in the West by the Mediterranean, in the East by the Jordan river (Deuteronomy, iii, 17); the Southern boundary was at Gaza (Joshua, xi, 22), and only the Northern boundary was at Sidon (Genesis, $x, 19$ ) a little to the north of the present frontier of Palestine, at Ras-al Nakura.

The country lying to the East of Jordan was called the land of Gilead. In the Bible, the Northern and the Southern boundaries are often defined as "from Dan to Beer-Sheba," and the census made by Joab according to King David's order, was also carried out within the territory from Dan to Beer-Sheba (II Samuel, xxiv, 2).

The area of the land of Canaan during the above epoch constituted about 6,000 square miles, and the area of present populated Palestine is about 5,500 square miles. According to Brown's computation, on the basis of extensive data collected

by him, the density of population of Canaan by the end of the epoch described amounted to from 80-100 persons per square kilometre, i.e., from 200-250 persons to a square mile. On the 
territory of inhabited Palestine, at present, there are now living about 1,000,000 people, i.e., about $180-200$ persons per square mile. Thus the density of population of Canaan in the epoch mentioned was nearly equal to that of modern Palestine, or, perhaps, even somewhat higher.

If we add to this that from the time of the epoch described to the present there have been neither in Palestine nor in the surrounding countries any geological cataclysms which could change the physical surface of the country, as the mountains, the valleys, the rivers and deserts of ancient Canaan still exist in contemporary Palestine; we may come to the conclusion that, in spite of the considerable period of time which has elapsed since the epoch described, we have a series of comparable basic units, viz., the same physical surface of the country, the same or somewhat higher density of population, and, as we shall prove later, the same climate.

What sources, then, have we for studying blindness in Canaan? The Bible still is the literary source of information, most worthy of credit, for no new ones have yet been discovered.

The life of the contemporaries of this eternal book is expounded in the form of a narrative or a law. Every true story is a fragment of life fixed in words, and every law is the "authoritative regulation of social relations."

The picturesqueness and exactness of description peculiar to the Bible is such that it often gives the possibility of recognizing the clinical picture of the diseases described in general, and of eye diseases in particular. Certainly, the Bible is not a medical manual or a manual of sociology, and every investigator will make a mistake if he seeks in it the modern terminology for those or other diseases, or for those or other social phenomena. But those who have lived for a long time in Palestine have had the opportunity of observing sometimes how a group of blind men trudge after a half-blind leader along formerly dusty streets of Jerusalem or Haifa, holding one another by the shoulder or by the hand, and have seen how at the first false step of the leader the blind fall one after another into a ditch, or clamber up hill stumbling over stones in the road. Those who have seen all this will understand the enormous purposefulness of the undermentioned Bible legislation for the protection of the blind in that far off epoch.

Thanks to the conservatism of the East, many manners and customs of the Canaan dwellers described in the Bible, are still preserved among the rural Arab population and among the seminomadic Bedouin tribes. The ancient book often becomes a book 
of the recent day when read on the spot of its birth. Many sides of life in Canaan acquire the character of actuality, when compared with the contemporary life of Palestine, and even the blindness in Canaan and its causes may be explained when studying the causes and extent of blindness in modern Palestine.

According to the Census of November 18, 1931, "in Palestine 1968 persons in every hundred thousand are blind of one eye, while 843 persons in every hundred thousand are totally blind." As a matter of fact, "Palestine now takes the first place in the world in regard to the gravity of blindness." (Census of Palestine.)

Number of Persons afflicted per 100,000 of Population

\begin{tabular}{|c|c|c|c|c|c|c|c|}
\hline \multirow{2}{*}{\multicolumn{2}{|c|}{ Religion and District }} & \multicolumn{3}{|c|}{ Blind in one eye } & \multicolumn{3}{|c|}{ Totally blind } \\
\hline & & Persons ${ }^{*}$ & Malest & Females $:$ & Persons & Males & Females \\
\hline Palestine ... & $\ldots$ & 1,968 & 2,092 & 1,841 & 843 & 709 & 981 \\
\hline Moslems ... & $\ldots$ & 2,512 & 2,672 & 2,348 & 1.061 & 883 & 1,245 \\
\hline Jews & $\ldots$ & 260 & 287 & 232 & 139 & 149 & 131 \\
\hline Christians ... & $\ldots$ & 1,215 & 1,210 & 1,220 & 564 & 462 & 666 \\
\hline SOUTHERN DISTRICT & $\ldots$ & 2,802 & 2,867 & 2,734 & 1,137 & 946 & 1,338 \\
\hline Jerusalem District & $\ldots$ & 2,115 & 2,254 & 1,976 & 871 & 739 & 1,002 \\
\hline NORTHERN DISTRICT & $\ldots$ & 1,252 & 1,407 & 1,092 & 606 & 512 & 703 \\
\hline \multicolumn{2}{|c|}{$\begin{array}{l}\text { Gaza Sub-district } \\
\text { (Southern District) }\end{array}$} & 4,662 & 4,562 & 4,561 & 1,933 & 1,596 & 2,266 \\
\hline
\end{tabular}

Note.- ${ }^{*}$ Per 100,000 males and females together; t per 100,000 males only; $\ddagger$ per 100,000 females only.

This enormous estimate of blindness, however, is lower than the actual, as a certain number of the blind slip away from registration during a general census. The figures of the Sample Survey made personally by Dr. J. C. Strathearn, C.B.E., Warden and Chief Surgeon of the Ophthalmic Hospital of the Order of St. John in Jerusalem, approach more closely to the truth. This Sample Survey was effected in 5 villages in the Northern District - Tulkarem sub-district,- -and in 5 villages in the South of Palestine-in the Gaza sub-district,-in July and August, 1932. The villages were chosen by the Superintendent of Census. It appeared that in the villages in the South the percentage of totally 
blind constituted according to the Sample Survey 2.9 per cent.; and according to the Census 2.4 per cent.; and in the Northern District according to the Sample Survey 1.4 per cent. ; and according to the Census 0.69 per cent., i.e., it was double that of the Census. Taking into account the data of the Sample Survey, we may say without exaggeration that there are not fewer than 10,000 blind individuals in Palestine (according to the Census8172 ) among a total population of $1,035,821$, i.e., there is one blind of both eyes in every 100 persons.

However great the total number of blind individuals in modern Palestine is, this social group does not represent such a big factor in public and civil life that it should attract the attention of the legislator so much as to require the promulgation of a law protecting the life and personal safety of this considerable group of unfortunate people. In villages and towns among the settled population the life and the personal safety of the blind are really not exposed to any special aggressions nowadays in comparison with the seeing population.

In Canaan the situation of the blind was quite different. The number of the blind at that time evidently was so large, and their life and personal safety were exposed to such painful trials that as early as 1200 B.c. the legislator proclaimed a law for the protection of the life and personal safety of the blind.

This law was solemnly proclaimed in the centre of Palestine upon Mounts Gerizim and Ebal, in the presence of all the tribes of Israel :-

"And Moses charged the people the same day, saying, These shall stand upon Mount Gerizim to bless the people, when ye are come over Jordan; Simeon, and Levi, and Judah, and Issachar, and Joseph, and Benjamin; And these shall stand upon Mount Ebal to curse ; Reuben, Gad, and Asher, and Zebulun, Dan and Naphtali. And the Levites shall speak, and say unto all the men of Israel with a loud voice, ... Cursed be he that maketh the blind to wander out of the way. And all the people shall say Amen." (Deuteronomy, xxvii, 11-14, 18).

Evidently the enormous number of the blind during the wars for conquering Canaan presented a considerable impediment to the movements of the vanguard, as well as in the rear; and, in order to get rid of this unnecessary human incubus, the cruel manners of that time permitted the indication of a false direction to the blind who, owing to his deception, fell into the hand of the enemy or perished having been led astray. This law shows that misleading the blind was a very usual and wide-spread fact; otherwise it would not have drawn such an exceptional attention from the legislator. The threat of cursing the whole nation evidently was not a simple rhetorical turn of phrase but called forth 
consequences effective enough for taming even the wild manners of the time. The severity of punishment testifies to the energy of the justice of those days in fighting to protect the life of the blind. Punishment for misleading a blind man was as severe as the penalty for the violation of such important laws as :- "Cursed be the man that maketh any graven or molten image; Cursed be he that setteth light by his father or his mother." (Deuteronomy, xxvii, 15, 16).

This law for safeguarding the blind, proclaimed by Moses, was given at the beginning of the conquest of Canaan by the children of Israel, i.e., in the time of the wars, but the subsequent legislator in the time of peace also could not ignore such a clamorous and horrible fact as the miserable status of the army of the blind.

In Leviticus (xix, 14), the legislator again enacts the law of safeguarding the life of the blind in a somewhat different way :"Thou shalt not curse the deaf, nor put a stumbling'block before the blind."

The wild mannered people of the time probably had often made fun of the numerous helpless and defenceless blind by placing all kinds of obstacles in their way; and these practical jokes often ended with mutilation and, may be, even death of a blind invalid. Evidently this making fun of the blind was also a common occurrence and happened frequently. For on the basis of rare occurrences the legislator would not have found it necessary to promulgate a special law prohibiting similar jeering at the blind. This law, as well as the above mentioned, points out the difficult position of the blind in the social order of that time. This appalling position of the blind is described in Deuteronomy (xxviii, 29), in the following way:- "And thou shalt grope at noonday, as the blind gropeth in darkness, and thou shalt not prosper in thy ways; and thou shalt be only oppressed and spoiled evermore, and no man shall save thee."

From the legislation quoted and from the description of the miserable position of the blind we can draw the conclusion that not only were the conditions of their life difficult in that time but that the blind were so numerous, and composed such a considerable group of the population as to make it impossible for the legislator to disregard such a prominent social factor of his time. 1 per cent. of the blind in our days, evidently, is a very small percentage in comparison with the number of the blind in Canaan. 10,000 blind in the country have not attracted the attention of the modern legislator, in spite of the doubtless greater humanity of the authorities in Palestine nowadays. Evidently in Canaan, with its population equal to that of Palestine now, the number of the blind must have been many times greater, computable at a hundred thousand and possibly more, if it drew the attention of the legis- 


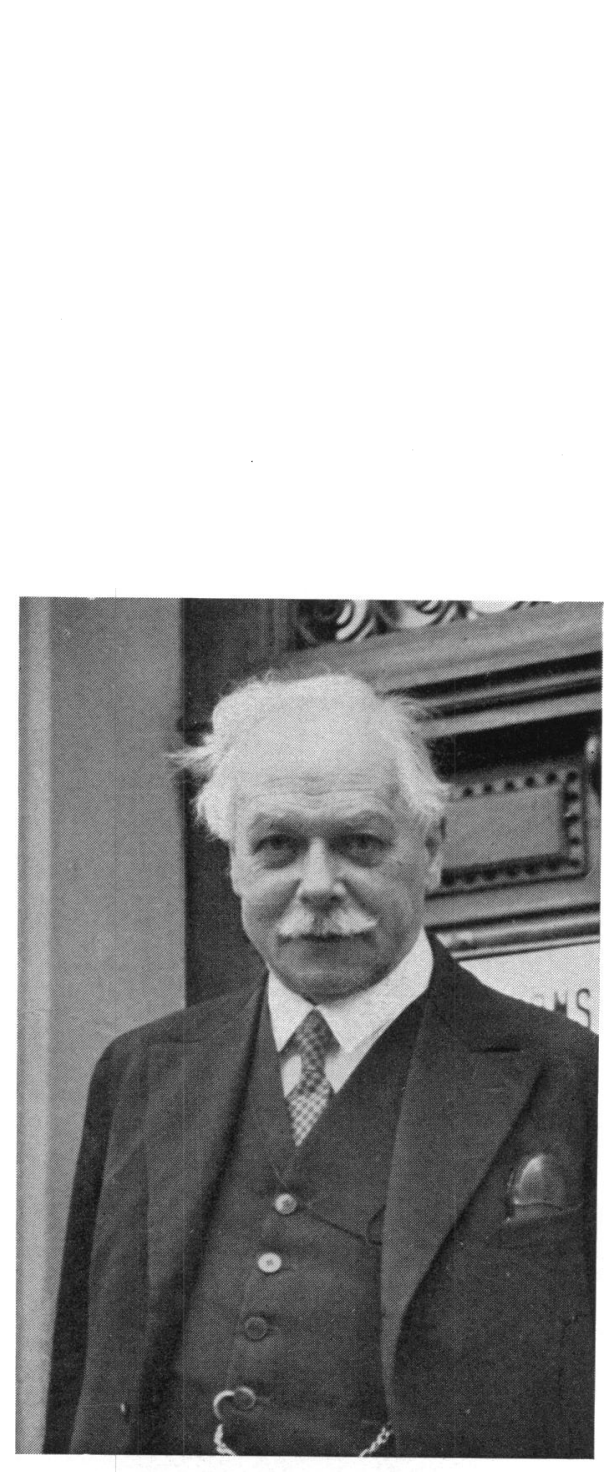

$\underline{\underline{T}}$

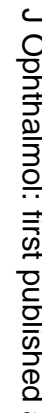

है

$\overrightarrow{0}$

$\overrightarrow{\vec{\omega}}$

$\vec{\omega}$

JULES GONIN

응.

$\vec{\circ}$

ن্

오

○

윰

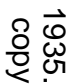

흑ㅇํㅇ

$+$

임

จำ

궁

골

훙

흥.

훌.

ชิ

오

금

N

.

กิ

స్ట

У

$\stackrel{0}{\mathbb{D}}$

뭉

离

(1) 
lator of those times in spite of the cruel manners of antiquity. As we shall see further, this enormous figure is probably not far from the truth.

A law quoted hereafter indicates that blindness was wide spread not only among the lower classes of the population but also among the higher orders to which the Levites-priests and guardians of the law, simultaneously belonged. As priests, the Levites were exempted from military service (Numbers, xlix, 50), and therefore were not exposed to the danger of losing their sight in war, which in past wars (except the World War) occurred more often as a result of various infectious eye diseases than from eye wounds (Shimkin ${ }^{5}$, Axenfeld, Meyerhof ${ }^{1}$ ). Besides that, the Levites lived exclusively in towns as, according to law, the servants of the Lord were to receive no land share (Inheritance) and in consequence of this the Levites took no part in agriculture. (Numbers, xxvi, 62; Deuteronomy, x, 9; Joshua, xiii, 14, 33 ; xviii, 7). Thanks to a great number of studies of the extent of blindness among classes of divers nations, we know that blindness is spread among the rural population much more than among the town folk. In modern Palestine, according to the fore-cited table, the rate of blindness is exceptionally great among the Moslems, of whom 75 per cent. compose the rural population; among the Christians, 76 per cent. of whom live in towns, the incidence of blindness is only half as great. The very small percentage of blindness among the Jews in Palestine is explained by a whole series of causes mentioned by the author in the article entitled "Blindness among Jews in Palestine and its causes." But one of the causes is that Jews also form predominantly the town population. And yet among the Levites, town dwellers cultured and privileged, total blindness was such a frequent occurrence that for the sake of safeguarding the decorum of the service the legislator had to proclaim a special law prohibiting the blind Levites as well as other cripples from taking part in the sacrifices.

"For whatever man he be that hath a blemish, he shall not approach, a blind man, or a lame, or he that hath a flat nose, or any thing superfluous." (Leviticus, xxi, 18).

The fact that the blind were mentioned first among the various kinds of cripples indicates also that blindness among the Levites occurred oftener than other physical defects.

Not only was total blindness among the Levites of frequent occurrence but eye diseases leading to partial loss of sight were also frequently met with among this privileged class. In Leviticus (xxi, 19, 20), the same law prohibiting sacrificing by different invalids mentions that the following individuals should not be allowed to sacrifice : "Or crookbackt, or a dwarf, or one that hath a blemish in his eye, or be scurvy." The word 
"blemish" is translated in the Vulgate as "albuginem habens in oculo," i.e., leucoma corneae, in Arabic translation of the Bible "ainayhi bayad" (his eye is white); in Tobias (2, 9. 3, 17, $6,8)$ the word "Blemish" was translated in Greek-leucoma.

These cases of partial blindness are numerous in Palestine of to-day too. According to the above table, there are almost $2 \frac{1}{2}$ times more persons blind in one eye than in both eyes. It is certain that blindness of one eye among the Levites was also a frequent occurrence, otherwise the legislator would not have issued a special law concerning the partial blindness of the Levites. The above laws referring to the total or the partial blindness of the Levites should lead us to the logical conclusion that if blindness and diseases resulting in it were spread so much among the privileged town class, then the same affliction and diseases causing total or partial loss of sight were spread much more among the lower orders who in the whole world are more afflicted with eye diseases than the cultured and privileged classes of the country. (Wibaut).

But besides the above-mentioned laws which are the truest reflection of the extent of blindness in Canaan, the Bible contains a whole series of stories confirming the immense spreading of blindness in Canaan before its conquest by the children of Israel.

These narratives of antiquity acquire the character of authenticity when one compares them with the extent and character of eye diseases and blindness in modern Palestine. Blindness in Canaan, as in Palestine now, was more common in the South than in the North. According to the above table the incidence of blindness in the Southern District of Palestine is twice as great as that in the Northern District.

The number of the blind in the South of the land of Canaan was so great that it composed a whole army mobilized in case of war for the defence of fortress walls either by means of intimidating the enemy by their very number placed on the fortress walls or for the execution of some mechanical works for frightening the enemy.

Thus, the following extract in the Bible which tells us about the conquest of Jerusalem by King David, bears witness to the enormous extent of blindness in Jerusalem itself and its environs :- "And the king and his men went to Jerusalem unto the Jebusites, the inhabitants of the land, which spake unto David, saying, Except thou take away the blind and the lame, thou shalt not come in hither." (II Samuel, v, 6).

Certainly, such a declaration might have been made by the Jebusites as a mockery, as if King David, they said, were so weak in comparison with them that even the cripples, such as the blind and the lame, might force him back. But on the other hand, the 
very comparison speaks on behalf of the fact that blindness was a habitual generalized feature of the country, as every comparison is suggested to the speaker by its reality, and in its clearness should be comprehensible to those for whom it was intended.

And without doubt King David knew that there were many blind among the Jebusites, otherwise the threat itself or even jeer would have had no meaning at all. It is also obvious that the Jebusite army of blind and lame cripples took an active part in repulsing David's troops, and routed them to a considerable extent when they took the stronghold of Zion of the Jebusites :"And David said on that day, Whosoever getteth up to the gutter, and smiteth the Jebusites, and the lame and the blind, that are hated of David's soul." (II Samuel, v, 8).

The army of the blind and the lame was enormous even 500 years after David's reign. When Jews at Judea were being led away into the Babylonish captivity the prophet Jeremiah consoled the people with the following words :- "I will bring them from the northern country, and gather them from the coasts of the earth, and with them the blind and the lame, the woman with child and her that travaileth with child together; a great company shall return thither." (Jeremiah, xxxi, 8).

This enormous extent of blindness in Canaan was called forth by a whole series of causes, as will be pointed out below, $\cdot$ but tradition has handed the records of mass losses of sight in the South which used to smite the population both small and great, even at the beginning of the epoch described. (Genesis, xix, 11). A similar instance of temporary mass blinding occurred among the Syrian troops in Northern Palestine near Dothan during their war against Israel (II Kings, vi, 18). "And when they (the Syrians) came down to him, Elisha prayed unto the Lord, and said, Smite this people, I pray thee, with blindness. And he smote them with blindness according to the word of Elisha."

The two cited cases of mass epidemics of eye diseases leading to temporary loss of sight happened, as was mentioned, at quite different epochs; one in Lot's days (about 1400 B.c.) the other considerably later in the days of Jehoram the son of Ahab (850 B.c.) and are doubtless a record of epidemic eye diseases affecting the peaceful population as well as the troops. The rapid spread of epidemic eye diseases can still be observed in the summer months in Palestine.

One of those extraordinarily severe eye epidemics caused by the Koch-Weeks bacillus, in 1922 attacked in a short time about 300 Russian immigrants, both young and old who temporarily lived under most difficult hygienic conditions in Haifa. (Shimkin ${ }^{2}$ ). In those olden times this epidemic might have been interpreted as a temporary blinding, a punishment by the will of the Lord. 
What causes then favoured the appearance and spread of blindness and of eye diseases in Canaan?

These causes were of two kinds. One will be called the external, and the other the internal. Under the term external causes we mean importing of contagious eye diseases into Canaan out of the neighbouring countries afflicted with them either by means of immigration or war campaigns. Under the term internal causes we mean the living conditions of the people in Canaan at that time, i.e., the sanitary condition of the country, insufficient medical aid, the influence of the climate on the development of the eye diseases and the presence or the absence of eye diseases in Canaan itself, independent of the neighbouring countries.

The transfer of infectious eye diseases by armies is spoken of more than once in the history of wars. Dr. Max Meyerhof's excellent monograph "A short history of ophthalmia during the Egyptian Campaigns of 1797-1807" illustrates very clearly by means of facts how in Egypt entire garrisons fell ill with acute conjunctivitis and trachoma owing to the absence of proper sanitary measures of prophylaxis and isolation, and how those garrisons when transported home infected the peaceful population along their way, in the ports, etc., and sowed blindness in Europe and in England. The influence of peaceful emigration from coumtries infected with eye diseases into countries not infected is known to everybody. Particularly in the East, it is still continuing at present. Dr. J. Hindway points out that in Arabia (Hedjaz) trachoma is observed amongst persons who have lived for some time in trachoma-infected countries (India, Mesopotamia, Egypt, Syria, Palestine) while there is no trachoma among the remaining population. Prof. Dr. Riza Said points out that although trachoma is spread considerably in Syria and even in the Horan uplands, one of the reasons of the increase of trachoma cases in Syria in summer time is that during these months communication is increased with countries suffering from trachoma, such as Iraq, Transjordania, Persia, Palestine and Egypt.

From the earliest times (and up till the present) Canaan has been the country across which led the "caravan road" of peaceful and military communications between countries lying to the North and to the South of it. It is obvious that if there were contagious eye diseases (such as trachoma and acute conjunctivitis) in countries surrounding Canaan, these diseases might have been easily brought into Canaan.

As is known, a long time before the coming of Abraham and of his tribe into Canaan, the country was under the influence of the Babylonian and the Egyptian cultures. Babylon has certainly left Canaan not only its literature and its laws but doubtless also its medicine and its physicians, who treated eye diseases resulting 
in blindness. And although we know very little about eye diseases in Babylon (Hirschberg), from Hammurabi's code and the Biblical narratives we may draw the conclusion which the writer will try to prove below:- that eye diseases causing blindness were widely spread in Babylon.

The close connection which existed between Canaan and Egypt is not subject to any doubt. A series of archaeological excavations in Palestine itself (Albright) and in Egypt point to the fact that Canaan was dependent upon Egypt as a vassal long before the coming of Abraham and his tribe, and that military garrisons and peaceful Egyptian settlements existed long before Canaan was conquered by the children of Israel.

Trachoma and different forms of acute conjunctivitis, i.e., diseases causing blindness were spread in Egypt from time immemorial. According to Boldt's expression :- "Trachoma in Egypt is as old as the Nile, the simoon and the desert." Meyerhof points out that the Ebers Papyrus (1553-1550 B.c.) "clearly distinguishes, for example, leucoma of the cornea and trichiasis, both of them sequels of severe, acute or chronic forms of conjunctivitis." In reliefs still preserved in Egypt the blind are represented with empty orbits (Greeff), i.e., with atrophy of the eye-ball (shrunken globe). It is of interest to note that one of the reliefs -7 blind musicians-refers to 1558 в.c., i.e., approximately to that epoch when Abraham and his tribe came to Canaan, and the other relief-a blind woman with a harp-to 1200-1174 B.c. (Greeff), i.e., to the years of Israel's exodus out of the Egyptian bondage. Thus, the reliefs clearly demonstrate that in the days of Israel's abode in Egypt under most difficult conditions of slavery (Deuteronomy, xxiv, 18,22 ; xxvi, 6,7 ), the eye diseases resulting in atrophy of the eye (i.e., acute conjunctivitis and trachoma), were wide spread in the country.

In order to prove objectively how thousands of people having come from a country free from trachoma may catch the disease in a trachoma-infected land in a short space of time, the following example taken from the life of modern Palestine is cited:Twenty-five years ago Jews of Yemen, a country which has no trachoma, according to Hindway's statement, began emigrating into Palestine. According to Dr. Feigenbaum's investigations in 1913 , and the last investigation of Dr. Sinai, Yemenite Jews had not suffered from trachoma at home, and now, among 1586 persons examined by Dr. Sinai, there are 856 persons having trachoma, i.e., $51 \cdot 3 \frac{1}{2}$ per cent. Certainly, one should not forget that these Yemenite Jews have lived as free citizens, while in Egypt the Israelites lived under the most difficult conditions of bondage. This example entirely confirms MacCallan's opinion that "there is no doubt that trachoma was rife in Egypt during the period 
of the Israelitish bondage in the country. It is almost inconceivable that the Israelites should not have brought it away with them as one of their less desirable forms of plunder." Certainly, beside trachoma they also plundered acute conjunctivitis resulting in atrophy of the globe of the eye which still composes 22 per cent. of all the blind in Palestine (Strathearn). Gonococcal conjunctivitis is the main cause of this atrophy. "Both in Palestine and in Egypt gonococcal conjunctivitis is due to epidemic and not to sexual origin, although a whole series of bacteriological investigations has established the identity of the gonococci of the eye conjunctiva with the gonococcus of the urethra." (MacCallan, Wilson). But eye diseases might have been brought into Canaan from other neighbouring countries affected with trachoma, such as Horan. There are plausible proofs in the Bible that eye diseases, and in their number trachoma, were spread in the ancient just as in the modern Horan.

In Genesis (xxix), it is said that Jacob's uncle, Laban, a rich farmer (fellah) who lived in Horan had two daughters:- Leah and Rachel, Leah having sore eyes. "Leah was tender eyed; but Rachel was beautiful and well favoured." On the question of Leah's disease, there is a comprehensive literature collected by Kotelman. An interesting note about Leah's eye-disease : "Ophthalmological item for the Bible" and an erudite letter To the Editor : "Leah tender or sore-eyed" are to be found in the Brit. $\mathrm{Jl}$. of Ophthal., 1930, p. 190 and 250-252. The writer's personal opinion on the character of Leah's eye disease is founded on the following items:-(1) On the basis of personal acquaintance with eye diseases in Palestine, and with the habits and customs of the rural Arab population, and (2) on the basis of studying the Bible text from the moment when Leah's name is mentioned first (Gen., xxix, 16) up to the birth of her first three sons (Gen., xxix, 23, 30, 31, 32, 33, 34). On the basis of all these data the outhor takes upon himself the liberty of saying that Leah suffered from a severe form of trachoma of both eyes, with ulcerated corneae associated with photophobia and blepharospasm. In order to shelter her eyes from light she bent herself, cast her head down and covered her eyes with her hands, as patients suffering from the same form of trachoma are doing to-day. The painful expression of the face each time the eyelids are opened disfigures the features of the young girls who have such a form of trachoma; streams of tears running down the cheeks make the appearance of these patients still more unattractive. Such a state, when complicated with trichiasis, may continue for a very long time, even years. As a result, opacity of the cornea of varying intensity appears:-nebula, macula, leucoma corneae, and the disfiguration remains constant. The 
exact author of the narrative did not want to say that Leah was neither well built nor beautiful. He only pays attention to her sore eyes and contrasts her with the well-shaped and beautiful Rachel. This comparison gives the contemporaries the possibility of drawing the conclusion, well known to them from the experience of life, that Leah's eye disease was such that it deprived her of the luck of being beautiful and "well favoured" as was her younger sister Rachel. Leah's eye disease made her so unattractive that Laban, her father, had no hope of seeing her married otherwise than by means of a deceit, as Leah, for those times, was no longer young. And the fact that Laban, a rich fellah (farmer) had a daughter almost becoming an old maid, speaks in favour of the conclusion that her eye disease was the main cause of her spinsterhood. When already married, Leah complains that she is not loved ("hated") after she had born Jacob three sons. Whoever knows how felaheen and Bedouins cherish wives who bear them sons, will readily understand that Leah's appearance must have been very unattractive if three sons had not made Leah's husband care for her; and the reason of this unattractiveness was, as the writer has pointed out, only that Leah was "tender eyed," i.e., that the severe form of trachoma with trichiasis and pannus ulcerosa, and afterwards leucoma corneae, and possibly staphyloma, had disfigured Leah's face. Obviously the type of women with such sore eyes was frequently met with in Horan and in the neighbouring Canaan, if the author considered his brief description of Leah's eye disease sufficient to acquit Laban's action in deceiving Jacob and to explain Jacob's strong hate of Leah. Leah's eyes are the characteristic state of the eye diseases in Horan and in Canaan where she spent the greater part of her life till her death.

The most powerful neighbour on the north-east of Canaan was Babylon. 2250 B.c., several hundred years before the coming of Abraham and his tribe into Canaan, Hammurabi's code states that there were so many eye diseases and so many practitioners who treated these diseases by operations that it was necessary to regulate the relations between these sections of the population. Hammurabi's code fixes a very high fee for a successful eye operation, viz., 10 silver shekels (\$215). Evidently, then, physicians performing an operation successfully were rarely met with, and only the rich classes of the population could afford to apply to them. Cutting the hands off was fixed as punishment for an unsuccessful operation which caused blindness (\$218). Obviously, there were so many unfortunate operations, and blindness was such a frequent consequence of the operation that the legislator 
considered it necessary to introduce the severest measures of punishment in order to stop such a cause of blindness. It is surprising that the law of cutting off the hands for an unsuccessful eye operation has remained a custom in modern Persia.

"As is known, Persians are the sole direct pupils of Babylonians from whom they have received their medical tradition." (Magnus). Dr. Polak reports a case which he witnessed in Persia 70 years ago. This information illustrates clearly the popularity of Hammurabi's laws which have survived thousands of years; a dervish in Teheran advertised his ability to heal trachomatous pannus. Five Persians having trachoma went to him to be healed. "The Dervish having demanded from each several ducats, and having given against them a written declaration that in case of failure he granted to each the right to chop off his hand, cut so unscrupulously into the eyes that the five patients operated on lost their vision owing to symblepharon." Probably Hammurabi had in view this kind of surgeon and such patients who had trachoma with corneal complications and not the operation for cataract which is mentioned in all manuals of medicine.

Magnus cites literal translations of paragraphs 215 and 218 made by qualified Assyriologists v. Oeffele and Vinkler. In Hammurabi's text the disease with regard to which the law is promulgated is called Na-qab-tu. Dr. v. Oeffele translates this word as "cataracta" (der Star); Dr. Vinkler-"Hollow or Split". ("Hoehlung oder Splate"). Having no special knowledge of Assyriology, the writer, as an ophthalmologist, thinks that senile cataract is not such a disease as to demand an immediate surgical intervention. Cutting the hands off was fixed as a penalty for an unsuccessful operation on a non-blind, and not on a blind eye, such as an eye with a mature cataract practically is. An unsuccessful operation for cataract does not restore the sight to the operated eye, but does not destroy it either. We have no information at all whether cataracts were spread as widely in Babylon as in India. (Elliot, Bagghi). On the other hand, we know that Abraham and his tribe (his father, wife and Lot) who came from Babylon lived until extreme old age with good vision. As now in Palestine so then in Canaan and in the neighbouring Babylon senile cataract appears in extreme old age. The following is written about Isaac and Jacob:- "And it came to pass, that when Isaac was old, and his eyes were dim, so that he could not see," and "Now the eyes of Israel were dim from age, so that he could not see." (Gen., xxvii, 1 ; xlviii, 10 ).

At that time, as well as now, not all old men with a senile cataract desired to be operated upon. Thus, Jacob was not operated upon, although Joseph had the best physicians of Egypt at his disposal (Gen., $\mathbf{x l}, 2$ ), and although among court physicians 
at that time there were specialists for eye diseases. (Meyerhof, Greeff). And now in Palestine, according to Dr. Strathearn's statistics, among a total of 1,118 blind eyes investigated the number due to senile cataract was 13 , and there were 7 cases where the other eye had lost its vision from some other cause, i.e., 20 cases altogether. This constitutes a group of about 200 in the total number of 10,000 sightless, i.e., 2 per cent. (or 0.02 per cent. of the total Palestine population). This percentage was hardly greater in Babylon. Such an insignificant group of the population, of which a still smaller part had been subjected to operation, could scarcely attract the attention of the legislator. Only a multitude of unsuccessful operations on eyes still able to see, which ended with blindness, could attract the attention of the legislator. Such a common disease might have been trachoma and its complications:-pannus and ulcers of the cornea which entirely corresponds to Vinkler's translation of the word "Na-qabtu" as Hollow-sulcus or split, in case of pannus crassus. Certainly, it is impossible to deny that operations "Depressio et Reclinatio Cataractae" have been performed in the east from ancient times. According to Elliot's investigations this oldest method of operation for cataract in India gives up to 20 per cent. of sight restoration within $0 \cdot 4-0 \cdot 1$ of normal vision.

Beside Hammurabi's code which leaves room for different hypotheses concerning the obscure word "Na-qab-tu," * it is possible to quote yet one Bible story testifying to the fact that in Babylon even the nobility were suffering from eye diseases leading to blindness. In the Bible the name of Balaam the son of Beor.living at Pethor in Mesopotamia is mentioned. He was a fortune-teller to whom kings turned for advice in the epoch of Israel's conquest of Canaan. (Numbers, xxii, 5, 7, 15; Deut., xxiii, 5). According to the eastern custom, Balaam fully enumerates his name and his personal marks lest he should be confounded with other predictors of the future. Beginning a speech he characterizes himself as follows (Numbers, xxiii, 3, 44) :- "And he took up his parable, and said, Balaam the son of Beor hath said, and the man whose eyes are open hath said." The verbal translation from the Hebrew runs as follows :Balaam the son of Beor said and the man with the open eye has said ("whose eyes are open" is a free translation, because there is the singular and not the plural in the Hebrew original). As his second personal feature which distinguishes him from other seers of his twpe he points out that:- "He has said, which saw the vision of the Almighty falling into a trance, but having his

*Gressmann, Ungnad u Ranke translate the word "Na-qab-tu" as a "Tränensack Fistel ?"

The unsuccessful operation of an abscess of the lacrimal sac does not lead to blindness (N. Sh.). 
eyes open," in other words, Balaam's main feature which others lack is that he has only one open eye but during a trance both eyes are opened. Whether Balaam had an unilateral atrophy of the globe and the lid was therefore fallen in, while the other eye was normally closed by the lid, or whether he had a large staphyloma which the eyelid could not cover and therefore the eye was always open,-is a matter of conjecture; but the fact that Balaam was blind in one eye does not admit of any doubt, for if he looked as a normal man with both eyes he would have had no need to mention it particularly, for vision with both eyes is a normal state.

About 500 years later than the epoch described Cyrus, King of Persia, in whose possession Babylon was, suffered from an eye disease and begged the Egyptian King Almazin (560 в.C.) to send him the best of his oculists. Certainly, these two cases divided by centuries are insufficient for the purpose of forming a correct idea of the diseases and of the causes of blindness in Babylon. But now Mesopotamia (Iraq) represents a country infected 100 per cent. with trachoma, according to the data of the League of Nations (Wibaut), i.e., affected even more than Egypt (Sobhy, Wilson) and Palestine now (Ticho). (XIII International Congress). Undoubtedly this enormous extent of trachoma in Iraq is an inheritance of trachoma from ancient Babylon.

In view of the close contact between Canaan and Babylon, it is quite possible that a transfer of eye diseases from Babylon into Canaan had been taking place long before the Exodus of Israel from Egypt.

From all the above data we may conclude that all the countries surrounding the land of Canaan were affected with eye diseases leading to blindness. In Canaan itself which maintained the closest cultural, political and economic relations with those countries, eye diseases resulting in blindness, such as trachoma and various forms of acute conjunctivitis doubtless were also spread long before the Israelites conquered the land of Canaan.

As regards the establishment of internal causes favouring the increase of the rate of blindness in Canaan, we should point out first of all that one of the causes which still influence the spread of eye diseases existed then, too: this cause is the climate. Some authors hold that in those far-off times when Palestine was known as the land of Canaan its climate was more humid and milder than now. The cause of this was that Canaan was considerably more afforested than modern Palestine (MacCallan $\left.{ }^{1}\right)$. There are no data given to prove this statement, and what is more important, it is not pointed out in which epoch Canaan was 
afforested more than the present Palestine. In order to frame an opinion on the extent of Canaan's woods in the epoch described we still have the sole document-the Bible, and in it the woods in Canaan are mentioned four times during its conquest by Israel. All these four times a forest is mentioned only in the environs of Jerusalem :-

(1) Kiryath-jearim (Town of Woods), where the very name indicates that this was an exception in the country (Joshua, ix, 17; xviii, 15 ; Judges, xviii, 12 ; I Samuel, vi, 21).

(2) The forest in Emek-Rephaim (Valley of Giants), where the wood was a strategic point in David's battle with the Philistines. (II Samuel, v, 24).

(3) The wood to the south of Mount Ephraim, not far from Gibeah of Benjamin, mentioned in connection with Saul's battle with the Philistines. (I Samuel, xiv, 25, 26).

(4) And a forest in the land of the Perizzites and of the giants ; it is mentioned in connection with the conquest of Canaan by the children of Joseph (Joshua, xvii, 15, 18), but in Auerbach's opinion (p. 104) this wood was in Transjordania.

The woods mentioned could hardly cause a change of climate throughout all Canaan in comparison with the climate of modern Palestine. Obviously in other places there were no considerable woods, otherwise they would have been mentioned as strategic points during the wars. Mount Carmel in Ben-Amon's time (about 1110 B.C.) was probably covered with woods as it is now (Dr. Auerbach). Certainly, it is also important to take into account that during the wars of the Israelites with the Canaanites woods were being cut down for war needs, which also took place during the World War, when the Turks hewed down enormous tracts of woods in Palestine :- on Mount Carmel, in Hederah and in other places. That during the conquest of Canaan woods were also cut down extensively is seen from the fact that the legislator was induced to prohibit cutting down of fruit-trees, and had to regulate for what purpose cutting other non fruit-bearing trees, was allowed. (Deuteronomy, $\mathrm{xx}, 19,20$ ).

Therefore it is quite plausible to suggest that the afforestation of modern Palestine, and therefore the humidity of the climate of Palestine now, and of Canaan then, depended to an equal degree upon the quantity of rainfall, as is said in the Bible:- "drinketh water of the rain of heaven." (Deut., xi, 11). As now, the rainy season ended in the middle of March when the possibility of waging war commenced. (II Samuel, xi, 1). The greatest blessings for the country were the timely and abundant rains, the early and the late, and the plentiful dew. (Jer., v, 23; Deut., xi, 14; xxviii, 12). "I will give you the rain of your land in the season, the first rain and the latter rain," and the worst curse consisted in drought 
and scorching wind. (Deut., xxviii, 22), now called Shiroq (meaning East wind).

Droughts with accompanying bad harvests and famine occurred in Canaan in the days of Abraham, Isaac and Jacob, in David's reign and in the times of Judges and Prophets (Genesis, xii, 10; xxvi, 1 ; xlii, 5 ; II Samuel, xxi, 1. xxiv, 13 ; Ruth,i ; Joel, i, 10-12). And in our days intermittent droughts and bad crops are known, such as those which occurred during the last three years when the Government gave the fellaheen subsidies to purchase seed for sowing. The south of Palestine lacked water already in the days of Canaan, when our ancestors waged war with the Philistines for the wells in the Beer-Sheba region (Genesis, xxi, 25 ; xxvi, 19, 22, 25). Finally, the flora in Canaan, according to the Bible, did not require irrigation. This is "a land of wheat, and barley, and vines, and fig trees, and pomegranates; a land of oil, olive, and honey." (Deut., viii, 8).

The foregoing may bring us to the conclusion that Canaan's climate did not differ essentially from that of modern Palestine, and that the climate then was equally favourable to the development of an epidemic of acute conjunctivitis giving rise to complications of the cornea (ulcers, erosions), especially dangerous when associated with trachoma.

Therefore the writer holds that the spread of conjunctivitis depending upon rain and temperature was subjected to the same law in Canaan as at present. "If the curve of temperature be taken as a parabola with its apex upwards and that of rainfalls as a parabola with its apex downward the maximum conjunctivitis would follow the line joining the apices. Generally the maximum of conjunctivitis is observed in August and September," or three months after the last rains (Shimkin 1, 2, 3).

Taking for granted that the bacterial flora of acute and chronic conjunctivitis met with in Palestine and Egypt now is as old as the still unknown cause of trachoma, we should come to the conclusion that the main causes of blindness in Canaan, as in Palestine now, were trachoma and acute conjunctivitis. Therefore blindness in Canaan was caused by Leucoma corneae totale aut partiale or atrophia bulbi, as is still observed.

There are no indications in the Bible as to what percentage among the blind consisted of persons with leucoma corneae and what percentage of cases with atrophia bulbi, but the abovementioned leucoma-corneae among the Levites, the most cultured class of society, gives us the right to affirm that this cause of blindness was a result of acute epidemic eye diseases. The following quotation taken from the book of the Prophet Zachariah (xiv, 12) convinces us that atrophv of the eyeball occurred precisely as a result of acute enidemic conjunctivitis:- "And this shall be 
the plague . . . , and their eyes shall consume away in their holes." Zachariah, like all the prophets, borrowed his figurative examples from the every day life of the people, and therefore his prophecy, in particular concerning eye epidemics resulting in atrophia bulbi, was comprehensible to each of his contemporaries, as it is still to us who have occasion to examine blind patients with an atrophy of the eyeball-a result of an acute conjunctivitis.

What factors, then, besides the climate, favoured the spread of different forms of acute conjunctivitis, of their complications and of trachoma in Canaan? One of the most important of such factors was the war, or more correctly the frequent wars of smalllanded Canaan princes, then the long period of conquest of Canaan by the children of Israel, lasting about 200 years, and finally the civil wars of the Israelitish tribes and kings and their wars with the neighbouring countries.

It has been already mentioned that acute conjunctivitis and trachoma spread quickly among the troops and the peaceful population coming in touch with them, when proper sanitary measures are absent. During a war the miserable position of the peaceful population and the absence of proper medical aid are both circumstances which are highly contributive to the spread of the above-mentioned eye diseases and therefore of blindness. As an example the writer will cite below the figures of the incidence of trachoma among the Jewish schools in Palestine during the last war (Shimkin $\left.{ }^{4}\right)$ :- Before the War in Palestine, in 1913-1914, there were 26 per cent. active trachoma cases among 9239 pupils of Jewish schools; after the War, in 1918-1919, among 8506 pupils of the same schools there were 40.7 per cent. of active trachoma cases, i.e., active trachoma had increased $1 \frac{1}{2}$ times during four years of war time in Palestine. It would have increased still more had the War lasted longer.

Indeed, in Canaan during the period described war was a permanent state. The hard social conditions of the life of the population, viz., poverty, overcrowding and absence of culture constituted, as is known, the next important factor assisting the spread of eye diseases.

There arises certainly the question whether the Canaan population lived under the same unfavourable conditions which are met with among the Arab rural population, especially in the south of Palestine, according to a true and detailed description of Dr. Strathearn. First of all it must be pointed out that in a state as Canaan where slavery was legal, eo ipso, the bondage population suffered from every bad economic condition. The numerous laws for the protection of the hired, poor, needy, stranger, widow 
and orphan showed the very miserable life of the lower classes in that time (Deut., xxiv, 10-5, 19-21). Those very bad economic conditions forced even the Israelites to sell themselves into slavery (Deut., xiv, 11-12). It must be pointed out as well that the density of population of Canaan, as was mentioned above, was somewhat higher than that of modern Palestine. The whole population was sheltered in towns behind the fortress walls. Villages were situated near the town walls so that their inhabitants might quickly take refuge inside them during the frequent attacks of enemies. While in Palestine, according to the Census, there are only 23 towns and 666 villages, there were not less than 400 towns in Canaan, not taking into account the suburbs and villages (Brown). In the book of Joshua, 300 towns with surrounding suburbs are mentioned (Gordon).

The crowding in these towns, i.e., inside the fortress walls was enormous, if we take into account the small area of these towns according to the excavations. Jericho, within the fortress walls, in the times of Canaan, occupied 2:35 hectares. Inside their walls Taanach and Megiddo, formerly important strategic points, occupied 4.8 hectares and 5 hectares, respectively (Brown, according to Sellin). In war and in peace the citizens crowded together not only in the houses but in the streets too. These were so narrow that one could touch both walls with hands stretched out. Such streets may be seen now in the excavations of Gaza, the most powerful fortress of the Philistines which fell only under Solomon, in 960 B.c., owing to the joint efforts of the allied armies of Egypt and Judah. The area of the houses was usually equal to 16-20 square metres, wherein dwelt five or more persons (Brown).

The sanitary conditions of Canaan were such that pestilence was a frequent visitor of the country. Leprosy and other skin diseases affected the population. Various other epidemics are frequently mentioned in the Bible (I Samuel, v, 6; II Samuel, xxiv, 15 ; Deutoronomy, xxviii, 59,60 ). Such unfavourable social and sanitary conditions must have helped the spread of eye epidemics, and consequently of blindness. The words (Deut., xxviii, 28), "The Lord shall smite thee with blindness," were not rhetorical threats but an observation of reality.

And into that densely populated country affected with trachoma and with acute conjunctivitis the children of Israel came to settle, warlike tribes of the desert leading a nomadic life. These tribes lived in tents (Numbers, xxiv, 5,6), like present-day Bedouins; and their manners and customs were like thoses of the Bedouins of the desert (Genesis, xviii, 4- $千$; xxiv, 11). The narrow towns of Canaan seemed to be "great and goodly" cities to such dwellers of the desert (Deut., vi, 10). 
The conquerors brought into the country a new source of trachoma and acute conjunctivitis, caught in Egypt; and during the long wars they contributed to the spread of these diseases in Canaan. Truly, the children of Israel brought into the country a number of sanitary and hygienic laws, many of which are still unsurpassed. They knew about the contagiousness of every kind of pus-discharging disease (Shimkin ${ }^{6}$ ). Individuals with such purulent and contagious diseases were isolated. Quarantine was prescribed for persons with an unascertained form of disease, and for persons who had come in touch with patients suffering from a contagious disease. Personal hygiene including washing the hands, all the body and clothes when touching a person with a contagious disease, or a corpse was obligatory (Leviticus, xiii, xxiv, xv). Evacuation within the camp was strictly prohibited. Each soldier was to have a special "paddle" to dig with when he wanted "to ease" himself outside the camp ("Abroad") and had to cover the hole with earth (Deut., xxiii, 13-15).

But these sanitary measures were hardly applied by the conquered population. Contagious eye diseases could only increase in number during a war. But besides calling forth epidemic diseases a war itself is a purveyor of epidemic traumatic blindness. This factor played also an important part in the period described.

Certainly, there were no hand grenades and explosive bombs of different sizes causing an enormous number of head wounds as during a modern trench war. Eye wounds during the World War constituted 225 per cent. of all head wounds, according to the data collected by the writer (Shimkin $\left.{ }^{5}\right)$. But nevertheless one should not underestimate injuries to the head and eyes caused by stones in the wars of antiquity. The deadliness and exactness of a stone blow may be illustrated by the meeting of David and Goliath (I Samuel, xvii, 49). The Arab population skilfully use this weapon even now. In Haifa, during the disturbances of September, 1929, an Englishman driving a car was killed by a stone striking his temple. During the disturbances of May, 1921, the majority of the killed in Tel-Aviv died from head wounds produced by throwing stones, and a boy's eye wounded with a stone had to be enucleated in order to prevent sympathetic inflammation. And although in area the eye represents only 0.15 per cent. of the human body (Cohn), the number of eye wounds to the total number of body wounds caused during the World War, according to the data of the Russian army, was 14.8 times greater than the proportion of the eye to the body in size, a fact which is certainly explained by the peculiarities of its anatomical structure and the high physiological function of the organ of sight (Shimkin, ${ }^{5}$ p. 34 ). 
Finally, in times of wars in antiquity blindness due to sympathetic inflammation must have occurred very often. The clinical picture of this disease and its surgical treatment has been known only from 1840, thanks to the works of the English physician (Mackenzie). During the last war hardly any cases of blindness due to sympathetic inflammation were observed but the medical reports of the German army for 1870-71 mention that blindness of both eyes caused by sympathetic inflammation occurred in 99 cases, i.e., in 50 per cent. of all injuries of the eye (Axenfeld). Finally, during a war a whole series of injuries of the cornea caused by stone splinters, knotted branches and so on happens, which in past times must have led to blindness owing to the absence of proper treatment.

Blindness during the wars in former times occurred in many cases also as a result of the savage custom of putting out the eyes of war prisoners. In the Bible a case is mentioned of the forcible blinding of Samson taken prisoner by the Philistines :- "But the Philistines took him, and put out his eyes" (Judges, xvi, 21). When the conquered voluntarily agreed to be taken captive the conqueror often provided a condition that they would be left alive if their right eyes were put out. "And Nahash the Ammonite answered them. On this condition will I make a covenant with you, that I may thrust out your right eyes" (I Samuel, xi, 2). Zedekiah the King of Judah was blinded by Nebuchadnezzar:"And put the eyes out of Zedekiah" (II Kings, xxv, 7; Jer., xxxix, 7; lii, 11).

Certainly, blinding war-prisoners could not acquire a general character as this required much time, and besides the conqueror lost valued slaves - the former war booty. Only war-prisoners and persons of high standing were blinded. But the frequency of wars during the period mentioned being high, this cause also accounted for a sufficiently great incidence of blindness. In order to glorify a conqueror the Assyrians even used to represent in reliefs the scene of execution of enemies by means of blinding. The following engraving borrowed by the writer out of Soloveitchik's atlas illustrates how they put out the war-prisoners' eyes.

The custom of Assyrians of putting out the eves of war-prisoners survived in the country adjoining Persia until the end of the last century. Vámberry, the famous explorer of Central Asia', was present, disguised as a dervish, at this barbaric torture, in 1863. He describes his horrible impression as follows :- "I saw how at a sign from the executioner eight aged men placed themselves down on their backs upon the earth. Thev were then bound hand and foot, and the executioner gouged out their eyes in turn, kneeling to do so on the breast of each poor wretch; and after every 
operation he wiped his knife, dripping with blood, upon the white beard of the hoary unfortunate." In the days of the conquest of Canaan mutilating the war captives was a usual custom; they were blinded or their thumbs and the great toes were cut off (Judges, $i$, vi, vii). In the extract from the Bible quoted previously the words "the blind and the lame"-in plural or in singular are always met with side by side. The frequent mention of these invalids together, confirms once more the opinion that war in ancient times was a considerable factor in bringing about traumatic blindness. In peaceful times, too, mutilation and in particular injuring the eyes was of common occurrence in Canaan, and the legislator had to proclaim a law in order to extirpate this

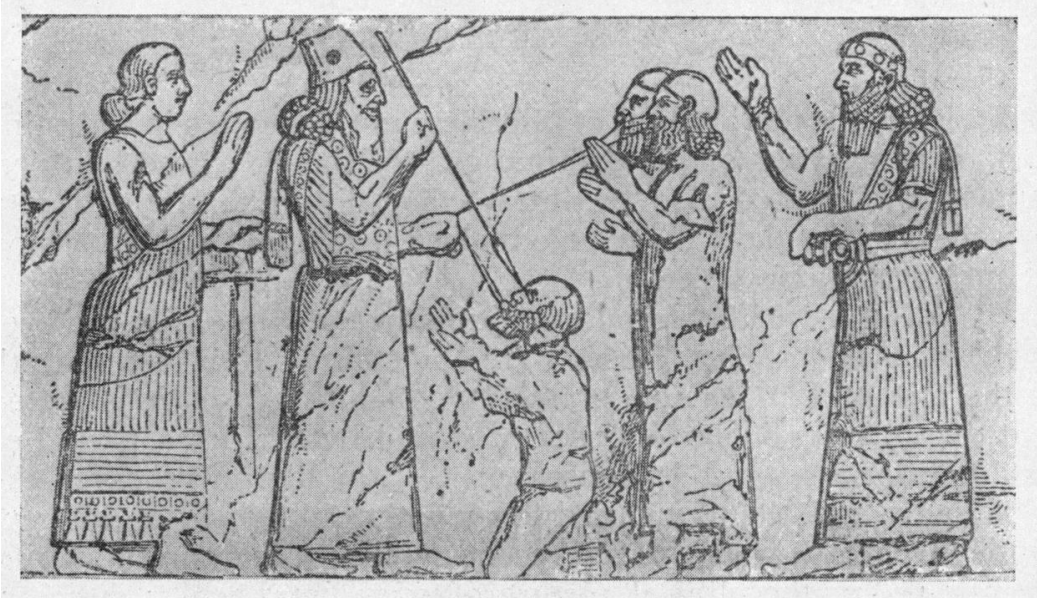

Assyrians putting out the eyes of war prisoners.

cruelty from among the children of Israel :- "And if any mischief follow, then thou shalt give eye for eye, .... tooth for tooth, ... foot for foot" (Exodus, xxi, 24; Leviticus, xxiv, 20 ; Deuteronomy, xix, 21).

Smiting the eyes of slaves was evidently also a favourite method of punishment with the slave owners, and this happened so frequently that in order to intimidate the slave owners and defend the slaves, a special law was issued (Exodus, xxi, 26) :- "And if a man smite the eye of his servant, or the eye of his maid, that it perish, he shall let him go free for his eye's sake." This law shows by itself that injuring the slaves' eyes was very frequent, and the punishment of a slave owner in the form of setting the slave free was for those times among the severest, because a slave cost 30 silver shekels. If we bear in mind that the daily wages of the worker at that time amounted to $1 / 30$ of a shekel then the 
slave owner lost 30 months of free labour. It is of great interest to note that the frequency of eye smiting during a fight was noticed not only by the law, but even found its recognition in popular proverbs. Instead of saying :- "You want to cheat or to deceive us," they said :- "Wilt thou put out the eyes of these men ?" (Numbers, xvi, 14). Certainly, in modern Palestine blinding during a fight also occurs among the Arab population, and an oculist may have several times a year to give his evidence as an expert as to the cause of the blinding of the injured, but these cases are on the whole rare. It is possible to say that in modern Palestine this factor of traumatic blindness of both eyes is absent, if single cases of total blindness due to the explosion of the dynamite used for exploding rocks when building houses and roads are not taken into account.

But while the main causes of blindness in Canaan (as in Palestine too), were diseases of the external coat of the eye, a certain percentage was caused also by intra-ocular diseases. In antiquity as well as in our days the people noticed that in old age the vision frequently became weak.

It is observed with special exactitude in the Bible that the eyes of the beloved prophet Moses were "not dim" even to his death at the age of 120 (Deut., xxxiv, 7). In other cases it is stated that due to intra-ocular diseases produced by senility a partial or total blindness set in. In consequence of the figurativeness of the Bible language, the terms used for denoting blindness of different kinds give us the possibility of reconstructing with a certain degree of plausibility the clinical picture of some intra-ocular diseases. Thus, it is said about Jacob:- Now the eyes of Israel were dim (Original-heavy)* for age so that he could not see" (Genesis, xlviii, 10), but at the same time it is observed that it was not a total loss of sight, for Jacob just before his death distinguished the faces of Joseph and of his sons (Genesis, xlviii, 11). The above clinical picture in connection with his age gives us the right to suppose that Jacob had a cataracta senilis nondum matura; and for a partial loss of the vision due to old age the expression was :- "eyes became heavy." Isaac's vision in his old age also weakened, but in a still higher degree than Jacob's :- "And it came to pass that when Isaac was old, and his eyes were dim, so that he could not see, he called his eldest son, and he said unto him, Behold, here am I." Isaac could not even distinguish the faces of the members of his family, and in order to recognize them

* The English translation interprets this and the following expressions alike, i.e., "dim"; but in the original there are three terms :-A'in kawed = Heavy eye ; A' in kehah =dim eye; A'in kama = immobile eye. 
was forced to have recourse to the senses of touch and hear; :- "The voice is Jacob's voice, but the hands are the hands of au" (Genesis, xxvii, 22). For such a total loss of sight the words im eye" (A'in kehah) are used in the Bible. In view of the old $e$ and the fact that the eye-ball is still taking part in the act of :ing, one should suppose that Isaac had a cataracta senilis itura.

But in the Bible there are mentioned other cases of absolute ndness due to intra-ocular diseases which senility involves. In ses of absolute blindness when sensitiveness to light totally appears, the eye-ball, as every oculist knows, remains mobile :- "the eye stands still" and does not move as an organ iich has no relation to the perception of light.

Juch a state of the eyes is twice mentioned in the Bible :-_"But lijah could not see : for his eyes were set by reason of his age" Kings, xiv, 4). This disease developed slowly. The vision appeared gradually till absolute blindness occurred. "And it ne to pass at that time, when Eli was laid down in his place, $\mathrm{d}$ his eyes began to wax dim, that he could not see" (I Samuel, 2). Only after a lapse of a certain time the absolute blindness in and the eyes became immobile (A'in kama) (I Samuel, 15). "Now Eli was ninety and eight years old; and his eyes re dim (Original-immobile), that he could not see."

The clinical picture described of absolute blindness in connection th old age gives us the possibility of supposing the presence of tucoma chronicum absolutum which still constitutes 26.3 per it. of all the blind cases among the Jewish population of Palese (Shimkin $\left.{ }^{1}\right)$. The figurative expression for absolute blindness s-"immobile eye" ("A'in kama"). Truly, cataracts, and in a tain number of cases glaucoma, refer to that kind of blindness iich may be removed by proper surgical intervention and srapy.

[ndeed, one of the causes and even the most important cause the enormous rate of blindness in Canaan was the absence of special medical ophthalmic aid. The latest archaeological zavations in Egypt show that there existed court oculists eyerhof, Greeff). But the masses could not afford to apply them, though possibly single persons made use of their aid. e high fees for a successful operation, fixed by Hammurabi, re valid not only in Babylon but also in the neighbouring lestine. Therefore mainly quacks were practising who helped some cases but in the majority of cases sowed blindness by ans of their unsuccessful operations.

In Biblical times eye therapy was probably in a more helpless te than surgery. The absence of accurate solutions of dical remedies $\left(\right.$ Meyerhof ${ }^{3}$ ) still more embarrassed the therapy 
of eye diseases. The situation of patients having an eye disease was hopeless. The hope of God's help was their own consolation :- "For I am the Lord that healeth thee" (Exodus, $\mathrm{xv}, 26)$. "The Lord openeth the eyes of the blind" (Psalm, cxlvi, 8).

It is of interest to note that if even now chirurgia est testimonium paupertatis medicinae, this truth was still more obvious in ancient Canaan and-what is characteristic as a survival of past times-the local population believes only in operative ophthalmic help. A fellah (farmer) attends an ophthalmic clinic to be operated upon and not to receive treatment.

The present state of medical aid in Palestine in general and of special ophthalmic aid in particular has reached a height unattainable for Canaan. And though this aid is still insufficient for the poorest rural population in the villages, yet the good means of communication constructed by the Palestine Government give the patient the possibility of reaching an oculist in a few hours and of receiving proper aid.

Therefore one of the very important causes of blindness in Canaan, namely, the lack of ophthalmic aid has become a comparatively insignificant factor in Palestine to-day.

If on the basis of all that has been said above we desire to answer the question put at the beginning of this article, viz., whether blindness and eye diseases were spread in the same degree in Canaan as in Palestine now, we should be obliged to answer that there were many more objective conditions favouring the spread of eye diseases and of blindness in Canaan than in modern Palestine. A whole series of factors causing blindness in Canaan are absent now : there are no uninterrupted wars which in ancient times were a source of the spread of blindness not only due to trauma but mainly due to infectious eye diseases. There are no cases of the forcible blinding of war-prisoners, and the cases of knocking out eyes of servants or of total blinding during a brawl are very rare.

Though the climatic conditions of the country still favour the development of acute conjunctivitis giving the highest percentage of blindness in Palestine, and though trachoma is still observed in 95 per cent. cases among the Arab peasantry, nevertheless the surgical and therapeutic aid give an undoubtedly better result in modern Palestine than in ancient Canaan. And though special ophthalmic aid to the poorest population is still insufficient, it was entirely absent in Canaan.

Certainly, the sanitary condition of villages in the south of Palestine, according to Dr. Strathearn's description, is rather pitiful, but in ancient times all Canaan was in no better condition. 
Although the children of Israel on their entry into Canaan brought in the idea of the contagiousness of pus-discharging diseases, thus including eye diseases $\left(\right.$ Shimkin ${ }^{9}$ ), and also the idea of isolating cases with contagious diseases and the fundamental knowledge of personal and social hygiene,-yet such sanitary measures as compulsory vaccination, isolation of contagious patients, disinfection of infected premises, are only now obligatory. The sanitary condition of Palestine at the present day with its numerous hospitals, dispensaries and clinics, Governmental and public, with their numerous medical staffs, stands on a height unattained by Canaan.

The prosperity of Palestine still growing, has already brought about a noticeable decrease of blindness in the north of Palestine (where it is half that of the south), thanks to the indirect income of the fellaheen from the Jewish settlers, and thanks to the cultural influence of the Jewish colonies upon the habits and manners of the Arab population (Strathearn).

Therefore a short answer to the question put is :-

The rate of blindness in Canaan was immeasurably greater than that of modern Palestine, and the eye diseases resulting in blindness in contemporary Palestine are a direct continuation of eye diseases which existed already in Canaan 3500 years ago.

\section{Summary}

1. The author states that the Land of Canaan in the epoch 1400-1000 B.C. had nearly the same area, the same density of population as the inhabited Palestine of to-day, the same climate and the same eye diseases resulting in blindness as in our days.

2. The proofs for the above are:-The ancient Bible laws for the protection of the blind in the time of war and of peace; the wide spread blindness among the privileged town classes such as the Levites; the narratives about mass blinding among the troops and the peaceful inhabitants, especially in the south of Canaan; and the proverbs and sentences of the prophets about the epidemics of eye diseases resulting in shrunken globes. All these historical facts are compared with similar causes of eye diseases of the modern Palestine.

3. The author notes that there were in Canaan two main causes for the spread of eye diseases resulting in blindness:-(1) The geographical situation of the land as "a caravan road" of peaceful and military communication between the neighbouring countries thoroughly infected with trachoma and acute conjunctivitis as Egypt, Syria (Horan) and Babylon, etc. ; (2) The internal causes : the hot and dry climate as in our days (contrary to the accepted opinion that in Canaan, in the epoch described, the climate was 
milder and more humid than nowadays), the poverty and ignorance of the lower classes of the population suitable for the state with the régime of slavery; the uninterrupted wars as a best source for the traumatic and infectious epidemics of eye diseases, blinding war-prisoners, the very bad sanitary condition of the land andlast but not least-the lack of special medical aid-surgical and therapeutic-for the population of old Palestine.

4. There are shortly mentioned the spread of trachoma and acute conjunctivitis in Egypt, in the epoch described, and new proofs are given for the spread of these diseases in Horan (Syria) and Babylon. The author expresses his opinion about eye diseases of our first mother Leah, and suggests that it was trachoma with corneal complications, and discusses the spread of infectious eye diseases in Babylon taking into consideration the Hammurabi code and the Old Testament narratives (story of Balaam's eyes). The author also gives his opinion and proofs that the obscure word in Hammurabi's code-naqabtu-means probably operation for trachoma and not for cataract or an incision of an abscess of the lacrimal sac, as it is admitted in many manuals when interpreting the word "naqabtu."

5 . The improvement of the economic and cultural conditions of the Arabic population to-day influenced by the Jewish colonization, especially in the north of Palestine, the peaceful development of the land under the rule of the British mandatory government; the present high sanitary state of Palestine and the medical special aid which can be obtained even by the poorest classes of rural population-taking all this into consideration the author came to the conclusion that the rate of blindness in Canaan was immeasurably greater than that of modern Palestine, and the eye diseases resulting in blindness in contemporary Palestine are a direct continuation of eye diseases which existed already in Canaan 3500 years ago.

6. At the end of this article the author speaks about the figurativeness of the Bible terminology for expressing the different grades of weakening of vision in connection with the old age. For absolute blindness the term is:-Immobile eye (Ain Kama); for sight weakening (as in the case of cataracta nondum matura) the term is :- Heavy eye (Ain Kaved); and for cataracta matura : -Dim eye (Ain Keha).

REFERENCES.

Annual Report of the Department of Health of Palestine; 1933, pp. 38, 44, 71. Albright, W. F.- The Archaeology of Palestine and the Bible. Second Edition, 1933, New-York London

Auerbach, E.-Wüste und Gelobtes Land. Berlin, 1932.

Axen?eld, Th.-Handbuch der ärtzlichen Erfahrungen im Weltkriege. Band 5 A ugenheilkunde, Leipzig, 1922, S. 124. 
Bagghi, Succumara.-Blindness in India. Calcutta Medical Journal, December, 1934. See: Annotation Brit. Jl. of Ophthal., March, 1935, p. 167.

Boldt, J.-Trachoma. London, 1904, p. 2.

Braun, S. - The Inbabitants of Palestine in the Time of Kings. (Special Edition in memory of Rabbi Zvi Peretz Hayat.) Vienna, 1933 (Hebrew).

Census of Palestine, 1931, Volume I, II by E. Mills, B.A., O.B.E., Superintendent of Census.

Cohn.-Klin. Wochenschrift, No. 8-9. Berlin, 1868.

Elliot, R. H. - Ophtalmologie Tropicale. Traduction française par Dr. Coutell and Dr. Morras. Paris, 1922, pp. 196-197, p. 155.

Feigenbaum, A. - Die Ansteckenden Augenkrankheiten Palastinas und ihre Bekampfung. Berlin, 1913, S. 13.

Greeff, R.-(1) Blindendarstellung in alten Aegypten. Klin.Monatsbl. f. Augenheilk., 1933, Januar, S. 82.

(2) Unser frühester Kollege, der agyptische Hof-Augenartz Iri. Klin. Monatsbl. f. Augenheilk., 1933, Marz, S. 395.

Gressman, Ungnad u. Ranke.-Altorientalische Texte und Bilder zum Altem Testament. S. 163-164, I Aufl., 1909, Tubingen.

Gordon, S. L.-Introduction to the book of Joshua, p. VIII. Varsovie. (Hebrew.)

Herodotus.-Encyclopédie française d'Ophtalmologie, Vol. I, p. 4.

Hindawy, S. - Trachoma in Arabia. XIII Concilium Ophthalmologicum, Amsterdam, 1929, Vol. III, p. 165.

Hirschberg, J.-Geschichte der Augenheilkunde, Kap. XXIII, S. 28. GraefeSaemisch Handb., Band XIII, II Aufl, 1899.

Kotelmann, L.-Die Ophthalmologie bei den alten Hebraern. Hamburg und Leipzig, 1910, S. 142-146.

MacCallan, A. F.- (1) Trachoma in the British Colonial Empire. Its relation to Blindness; The Existing Means of Relief; Means of Prophylaxis. Brit. Jl. of Ophthal., November, 1934, p. 639.

(2) Le rôle du gonocoque dans les ophthalmies purulentes des pays chauds. Assemblée généralle de l'Association Internationalle de Prophylaxie de la cécité et de l'Organisation Internationale contre le Trachome. Paris, Mai 14,1934, p. 80.

Magnus, H.-Zur Kenntniss der im Gesetzbuche des Hammurabi erwähnten Augenoperation. Deutsch. med. Wochenschr., 1903, No. 23, S. 416.

Mackenzie.-A practical treatise on the diseases of the eye. III Edition. London, 1840. See: A. Peters, Die Sympatische Augenerkrankungen. GraefeSaemisch Handb., III Aufl., S. 38.

Meyerhof, Max. - (1) A Short History of Ophthalmia during the Egyptian Campaigns of 1798-1807. Brit. Jl. of Ophthal., March, 1932.

(2) Cinquante ans de progrès Ophtalmologique en Egypte. Fol. Ophth. Orient., Vol. I, p. 5.

(3) L'Ophtalmologie de Mohammad Al-Châfiqîi; Supplément, p. 159, 1933. Masnou, Barcelona, Espagne.

Polak, I. Ed.-Persien und seine Bewohner. II Teil, S. 213. Leipzig, 1865.

Riza-Said.-Le Trachome en Syrie. XIII Concilium Ophthalmologicum, 1929. Vol. III, S. 162.

Sinai, A.-Das Trachom unter den Yemenitischen (Sudarabishen) Juden. Fol. Ophth. Orient., Vol. I, Fase 1, 1932.

Sobhy-Bey.-Le trachome en Egypte. XIII Concilium Ophthalmologicum, 1929, Vol. III, p. 168.

Shimkin, N. I.-(1) Blindness among Jews in Palestine and its causes. Congrés International de Mèdecine Tropical et d'Hygiene, Le Caire, Egypte, Decembre, 1928. Comp. rend., Tome III, 1931.

(2) Les Maladies des yeux à Caiffa/Palestine. Ann. d'Ocul., T. CLXI, Decembre, 1924.

(3) A contribution to the Epidemiology of the eye diseases at Haifa.. (Hebrew.) Harefouah, 1923, No 3-4, p. 194.

(4) Trachoma in Palestine. Its Epidemiology and a review of measures for dealing with it. Brit. Jl. of Ophthal., May, 1926, p. 254.

(5) Gunshot In juries of the Eye in the World War. Odessa, 1917. (Russian.) See: Brit. Jl. of Ophthal., Book Notice, November, 1927, p. 620.

(6) The most ancient law about the contagiousness of all pus. Harefouah, 1935 (Hebrew). 
Soloweitchzschik, M.-Die Welt der Bibel. Berlin, 1926.

Sorsby, A.-A short History of Ophthalmology. London, 1933, p. 2.

Strathearn, J. C.-The problem of Blindness in Palestine. Fol. Ophth. Orient., Vol. I, Fasc. 2-3. Jerusalem, 1933.

Ticho, A.-Zur Trachomfrage in Palestine. XIII Concilium Ophthalmologicum, 1929, Vol. III, p. 168.

Vámbéry, Arminius.-Travels in Central Asia. New York, 1865, p. 169.

Wibaut, P.-Mappa Mundi Trachomae. XIII Concilium Ophthalmologicum, 1929. Vol. III, pp. 12-13.

Wilson, R. P.-Ophthalmia Aegiptica. Amer. Jl. of Ophthal., Vol. XV, No. 5, May, 1932.

\section{A CASE OF ENDOTHELIOMA OF THE OPTIC NERVE SHEATHS}

BY

\section{H. B. Staliard}

LONDON

Endothelioma of the optic nerve sheaths is a relatively rare neoplasm but according to Byers the commonest of the tumours affecting these structures. Hudson in his paper about neoplasms of the optic nerve and its sheaths quotes 118 cases of gliomatosis, 29 of endothelioma and 6 of fibromatosis among the specimens and reports he collected. This neoplasm is composed of endothelial cells derived either from those adjacent to the dura and lining the sub-dural space or from the cells covering the fine connective tissue and elastic tissue strands which form the arachnoid mater. Mallory does not question this origin but considers that the histological term endothelioma is fundamentally incorrect and that arachnoid fibroblastoma would be more appropriate on the grounds that the endothelial cells are merely differentiated connective tissue cells. This conception is supported by the presence of collagenous and elastic fibrils in these tumours, probably produced by the endothelial cells under conditions of tumour formation. Neame comments on the fact that there is more fibrous tissue than could have arisen by the permeation of the neoplasm into the dural sheath and the sclera with the subsequent expansion of the fibrous tissue layers and lamellae of those structures.

The clinical features described in the literature conform in the main to the following summary. The number of cases reported is too small for statistics to have any significance, so these have been omitted for the purposes of this paper.

Females were affected more often than males and the maiority of cases were over 30 years of age, one case recorded by de Schweinitz was 11 and another by Neame was 79. Symptoms of failing vision were gradual in onset in most cases. Impaired movements were more common in cases of this neoplasm than in 